\title{
Fenomena Sosial Mikro-Makro Nahdlatul Wathan Era Orde Baru
}

\author{
Jamiluddin
}

IAIH NW Pancor Lombok Timur

Naskah diterima 20 Mei 2018, direvisi 28 Juni 2018, disetujui 18 Juli 2018

\begin{abstract}
This article discusses how Nahdlatul Wathan is prepared to care for the Islamic mission and the future of the country. Also include in some sub, this article examines the effort was done by Nahdlatul Wathan manifest his existence, for example, as system engineering organization that carefully conditioned with deep and widespread benefit standard. Study of integration efforts of the entire element, both micro as well as macro Nahdlatul Wathan became a staple part because that social phenomenon conspicuous in the dynamics of the Nahdlatul Wathan. Answering some doubts, trigger the interest analyze the awareness of Nahdlatul Wathan more conical in the post national tragedy, G30-S PKI. In more detail, the author loads the perception of Nahdlatul Wathan positioning the national tragedy above as a threat of the prestige of Republic Indonesia. The author then observe that the Nahdlatul Wathan at the beginning of the new orde era as it has come to a turning point to do something for his country and nation without support of hope space "what is given by Indonesia to Nahdlatul Wathan?". Nahdlatul Wathan in importance of optimizing his participation build a country, programmatically doing stages based on harakah was destabilizing the depend mechanism of the nation, especially the nahdliyin, so it is solid and firmly hold the national ideology as a manifestation of "hubbul Wathan" at once as a marker of religious settlement. These facts and phenomenon did not escape the spotlight in this article.
\end{abstract}

Key words: Nahdlatul Wathan, Micro-Macro, The New Order Era

Abstrak Artikel ini membahas tentang bagaimana Nahdlatul Wathan diprepare untuk merawat misi Ke-Islaman dan masa depan negeri. Include pula dalam beberapa sub, artikel ini mencoba menelaah usaha yang dilakukan Nahdlatul Wathan mewujudkan eksisitensinya. Misalnya saja seperti rancang-bangun system 
organisasi yang dikondisikan secara seksama dan dengan standar kemanfaatan yang in-deep dan meluas. Kajian tentang upaya integrasi seluruh elemen, baik mikro maupun makro Nahdlatul Wathan pun menjadi bagian pokok karena fenomena social itulah yang mencolok dalam dinamika Nahdlatul Wathan. Menjawab keraguan beberapa pihak, men-trigger kepentingan menguraikan kesadaran Nahdlatul Wathan yang semakin mengerucut pasca tragedy nasional, G-30-S PKI. Lebih detail, penulis memuat persepsi Nahdlatul Wathan yang memosisikan tragedy nasional di atas sebagai ancaman terhadap kemartabatan Negara Republik Indonesia. Penulis pun kemudian mencermati bahwa Nahdlatul Wathan di awal era Orde baru seperti telah sampai pada suatu titik balik untuk melakukan sesuatu untuk bangsa dan negaranya tanpa diboncengi dengan hope-space "apa yang diberikan Indonesia kepada Nahdlatul Wathan?". Nahdlatul Wathan dalam kepentingan mengoptimalkan kesertaannya membangn negeri, secara terencana melakukan tahapan-tahapan yang berbasis pada harakah menstabilisasi depend mechanism bangsa, khususnya nahdliyin, sehingga solid dan kukuh memegang ideology kebangsaan sebagai manifestasi " hubbul Wathan" sekaligus penanda kamapanan keberagamaan. Fakta dan fenomena ini pun tidak luput dari sorotan dalam artikel ini.

Kata kunci: Nahdlatul Wathan, Mikro-Makro, Era Orde Baru

\section{A. PENDAHULUAN}

Nahdlatul Wathan menjadi "berkah untuk negeri". Debatable tentang pernyataan ini sudah selesai, karena evidance secara normativ atau pun empiris sangatlah incredible. Nahdlatul Wathan hadir di negeri ini sebagai sebuah serpihan dari mozaik Indonesia dan Islam di Nusantara. Dengan maqoshid " Li'ilaikalimatillah Izzul Islam wal-muslimin, Nahdlatul Wathan survive membangun ummat untuk berkontribusi secara optimal dalam mengusung marwah Negara Kesatuan Republik Indonesia dan kemuliaan Islam.

Sejak berdiri untuk pertama kalinya pada tanggal 17 Rabi'ul Akhir $1372 \mathrm{H}$ atau bertepatan dengan tanggal 1 Maret 1953, Nahdlatul Wathan terus melaju dengan pertumbuhan dan 
perkembangan yang membaggakan. Setahun setelah berdiri, Muktamar I Nahlatul Wathan terselenggara dengan produk yang sangat positif. Selain menghasilkan beberapa suprastruktur organisasi, dihasilkan pula alat kelengkapan yang menjadi apendiks penting dan strategis dalam sistem organisasi Nahdlatul Wathan. Beberapa komponen tersebut adalah, penetapan organisasi sayap yang dalam terminologi Anggaran dasar dan Anggaran Rumah Tangga disebut dengan Badan Otonom dan Non Otonom Nahdlatul Wathan. Organisasi sayap ini tentu merupakan "ruang" yang diberikan kepada seluruh potensi efektiv organisasi untuk mengambil bagian dalam gerakan mewujudkan cita-cita mewujudkan masyarakat Indonesia yang beriman dan bertaqwa, merdeka, bersatu, berdaulat, adil dn makmur. Eskalasi organisasi Nahdlatul Wathan ternyata semakin menjanjikan. Beberapa kebijakan yang ditetapkan dalam Muktamar I Nahdlatul Wathan 1954, khususnya terkait dengan perluasan kesempatan bagi seluruh nahdliyin sesuai dengan status dan kapasitas, tampaknya memiliki makna tersendiri dalam mewujudkan sebuah gerakan yang massif. Artinya, potensi, baik ditingkat mikro-makro organisasi berpeluang berdenyut dalam bidang dan keahlian masing-masing untuk akselerasi pencapaian cita-cita mulia organisasi.

Pada pesta demokrasi pertama setelah kemerdekaan Republik Indonesia tahun 1955, mu'assis Nahdlatul Wathan mendapat kepercayaan untuk menjadi perwakilan Indonesia Timur menduduki jabatan sebagai anggota Konstituante atau setingkat Majelis Permusyawaratan Rakyat (Jamiluddin, 2002: 47). Sukses ini tentu menjadi effect eksistensi Nahdlatul Wathan sebagai mainstream di Lombok dan Sumbawa berkat effort pemberdayaan nahdliyin dari tingkat elite sampai dengan warga, termasuk pengkondisian kelembagaan, norma, dan lain-lain. Satu Windu sejak 1955 sampai 1963, Bapak Hamzanwadi atau pendiri Nahdltul Wathan sangat memanfaatkan kesempatan perjumpaan dengan tokoh-tokoh nasional yang secara kebetulan sedang mengemban amanah yang sama di Konstituante Republik 
Indonesia. Dalam perjumpaan tersebut, beliau bertukar informasi mengenai strategi pemberdayaan ummat yang efisien dan efektiv. Salah satu produk perjumpaan beliau adalah terbangunnya sebuah orientasi modern tentang pentingnya pendirian lembaga pendidikan tinggi untuk mempersiapkan sebuah "revolusi" utamanya terkait dengan system organisasi sehingga survive dalam menyesuaikan diri dengan dinamika ilmu pengetahuan dan teknologi yang mempengaruhi sistem sosial maupun global. Tepatnya pada tahun 1964, orientasi atau pandangan modern tersebut diwujudkan oleh Bapak Hamzanwadi dengan bantuan beberapa elite Nahdlatul Wathan berpikiran luas, dengan mendirikan Akademi Paedagogik Nahdlatul Wathan yang diikuti dengan pendirian Ma'had Darul Qur'an Wal-Hadits Al-Majidiyah Asysyafiiyah Nahdlatul Wathan Pancor pada tahun 1965 (Jamiluddin, 2002: 47).

Pada Tahun 1965, tepatnya pada tanggal 30 September terjadi kekacauan politik kenegaraan akibat sebuah gerakan yang dimotori Partai Komunis Indonesia. Akibat peristiwa ini, sistem politik Indonesia mengalami masalah. Demikian pula sektor ekonomi dan sosial menjadi tidak terkendali. Konsekuensinya, keamanan nasional cukup extreme dan tidak hanya di Ibu Kota, tetapi hampir diseluruh wilayah hukum Republik Indonesia menjadi locus terdampak yang membutuhkan penanganan secara professional dan proporsional (Yudi Latif, 2015: 350) .

Nahdlatul Wathan sebagai sebuah Organisasi Kemasyarakatan Islam di Indonesia tentu tidak dapat mengelak dari keniscayaan mengalami dampak tragedy G 30 S PKI tersebut. Tidak hanya terkait dengan internal Nahdlatul Wathan, tetapi bagaimana peeran Nahdlatul Wathan di tengah-tengah bangsanya dan atau ummat dalam lingkup yang lebih luas pun menjadi variable yang mesti serius disikapi. Bagaimana Nahdlatul Wathan pasca tragedy G 30 S PKI ini sangat menarik diungkap dan diurai, terutama bagi penulis. Sekiranya inilah hal yang menjadi latar kuat penulisan tentang Fenomena Sosial Mikro-Makro Nahdlatul Wathan Era Orde Baru 


\section{B. METODE PENELITIAN}

Dalam kajian Fenomena Sosial Mikro-Makro Nahdlatul Wathan Era Orde Baru ini, akan diurai secara mendalam tentang fenomena social mikro subjektiv dan objektiv serta fenomena social makro subjektiv maupun objektiv ( George Ritzer, 2005: 476-477) di lingkungan Nahdlatul Wathan selama kurun waktu Orde Baru, tepatnya selama 30 tahun. Nahdlatul Wathan sendiri adalah kelompok atau organisasi yang di dalamnya terdapat nahdliyin yang berkebudayaan sama. Sementara itu, Orde Baru yang dimaksud dalam kajian ini adalah suatu masa pemerintahan yang digerakkan oleh kelompok yang punya afiliasi tak tergoyahkan kepada Pancasila sebagai Dasar, Falsafah, dan Pandangan Hidup Bangsa Indonesia di bawah pimpinan Presiden Soeharto.

Dalam usaha memperoleh data dan bukti-bukti pendukung yang akan diolah untuk melakukan menjelaskan Fenomena Sosial Mikro-Makro Nahdlatul Wathan Era Orde Baru, peneliti "menenggelamkan diri" dalam komunitas atau nahdliyin. Baik di tingkat elite maupun anggota biasanya. Berdasarkan perimbangan ini, peneliti kemudian menetapkan untuk meneliti masalah ini dengan Metode Kualitatif dan Pendekatan Etnografi (John W. Creswell, 2015: 125-130). Dalam memperoleh data dan buktibukti pendukung, peneliti memilih metode observasi dan wawancara yang berlangsung hingga ketaraf jenuh (Emzir, 2012: 53) dan memilih informan kunci sebagai langkah awal mendalami persoalan Fenomena Sosial Mikro-Makro Nahdlatul Wathan Era Orde Baru. Sedangkan dalam hal menginterpretasi data dan infomrasi pendukung yang diperoleh, peneliti menggunakan pandangannya sendiri (menggunakan etnografi kritis) dan menurut apa yang diuraikan informan (etnografi realis). atau menggunakan etnografi kritis (John W. Creswell, 2015: 130).

\section{HASIL DAN PEMBAHASAN}

Fenomena Sosial Mikro-Makro Nahdlatul Wathan Era Orde Baru Kontinuitas pergerakan dan pengembangan Organisasi Nahdlatul Wathan ternyata dapat diejawantahkan. Ajaran "yaqin. Ikhlas, 
istiqomah" yang senantiasa diinternalisasi secara intensif oleh Bapak Hamzanwadi, pendiri Nahdlatul Wathan sangat mengkristal dan menjadi kekhasan dalam setiap harakahnya. Secara diakronik, pengkhidmatan pada era orde lama senantiasa menjadi pijakan gerakan pada pengkhidmatan diera Orde Baru. Inilah fakta mengkristalnya ajaran "yaqin. Ikhlas, istiqomah" Bapak Hamzanadi, pendiri Nahdlatul Wathan.

Era Orde Baru ditandai dengan pergantian kepemimpinan Negara dari Ir. Soekarno ke Jenderal Soeharto selaku Presiden dan Kepala Negara Indonesia pada tahun 1966. Pada waktu itu, Indonesia tengah berproses memulihkan keadaan Negara dan bangsa dari trauma masalah sosial dan politik kenegaraan akibat Gerakan Tiga Puluh September Partai Komunis Indonesia. Sebagai elemen bangsa, Bapak Hamzanwadi sekaligus Nahdlatul Wathan melakukan usaha-usaha sesuai dengan bidang yang ditekuni untuk memberikan support kepada Negara yang tengah dalam kondisi sebagaimana diuraikan di atas. Sikap koopratif Nahdlatul Wathan ini tidak hanya ditingkat aktivis, tetapi juga secara bertahap melalui jenjang organisasi disosialisasi secara terencana. Dengan demikian, daya dukung Nahdlatul Wathan kepada Negara dalam menunaikan kewajibannya ini berlangsung secara massif dan simultan. Di Majelis Ta'lim, termasuk di lembaga-lembaga pendidikan Nahdlatul Wathan sendiri, dukungan itu diberikan dengan mensosialisasi tentang bagaimana cara memperjuangkan tetap tegaknya Negara Kesatuan Republik Indonesia. Kurikulum 1968 yang bermuatan Pancasilais, pun diterapkan secara optimal disetiap lembaga pendidikan Nahdlatul Wathan dari jenjang Madrasah Ibtida'iyah sampai perguruan tinggi. Sikap koopratif dan kebersamaan Nahdlatul Wathan yang sedemikian positip ini, ternyata tidak hanya sampai disitu saja. Daya dukung ini dikonsolidasikan lagi dengan keputusan Bapak HAMZANWADI, pendiri Nahdlatul Wathan untuk ikut dalam kontestasi politik pada Pemilu Pertama dimasa Orde baru pada tahun 1971. Beliau dicalonkan oleh Sekber Golkar (Golongan Karya) untuk menjadi Anggota Majelis Permusyawarantan Rakyat Republik Indonesia. 
Langkah Bapak Hamzanwadi ini merupakan sebuah keputusan strategis dengan alasan bahwa ruang politik yang bertaraf nasional ini akan sangat mendukung percepatan pengembangan organisasi Nahdlatul Wathan, baik secara langsung maupun tidak langsung. Contoh akurat yang membuktikan kebenaran putusan beliau adalah ketika secara internal, Nahdlatul Wathan menetapkan usaha pendirian beberapa sekolah dan madrasah tingkat menengah untuk mensupport atau untuk mempersiapkan sekolah umpan bagi perguruan tinggi yang sudah ada terlebih dahulu. Dalam upaya itu, proses berjalan sangat lancar disebabkan karena birokrasi yang dilalui telah sangat difahami oleh beliau dan sesungguhnya juga disebabkan oleh effect singkronik dalam bentuk sikap koopratif Nahdlatul Wathan terhadap program pembangunan Nasional yang dicanangkan pemerintah selama ini.

Pendirian beberapa sekolah dan madrasah, tepatnya pada tahun 1973 sebagai sekolah umpan bagi perguruan tinggi, seperti Akademi Paedagogik Nahdlatul Wathan dan khususnya Ma'had darul Qur'an Wal-Hadits Al-Majidiyah Asysyafiiyah Nahdlatul Wathan Pancor sebagaimana keterangan di atas, pada hakekatnya memiliki tujuan tertentu. Secara eksplisit, pendirian sekolah dan madrasah tersebut adalah untuk memberikan alternative bagi anggota masyarakat, khususnya nahdliyin dalam menentukan lembaga pendidikan bagi generasi atau putera-puterinya. Jadi, Nahdlatul Wathan dalam hal ini ingin menyuguhkan pelayanan pendidikan kepada masyarakat dalam rangka membantu kelancaran program pemerintah. Sementara itu tujuan implisit adalah memperluas jangkauan sasaran kaderisasi secara berjenjang melalui jalur pendidikan formal. Sangat diyakini bahwa jalur pendidikan adalah satu-satunya jalur efektiv dalam usaha kaderisasi yang memberikan penjaminan lahirnya kader-kader yang bermartabat dan berkualitas.

Ketika jalur pendidikan, khususnya di tingkat perguruan tinggi mengalami beberapa kendala, khususnya kendala administrativ, Akademi Paedagogik Nahdlatul Wathan terpaksa ditutup. Namun karena jalur ini sudah terlanjur sebagai jalur primadona, maka 
Nahdlatul Wathan, memberdayakan kemitraannya dengan Yayasan Al-Mujahiddin dan Birrulwalidain Nahdlatul Wathan Pancor yang berpotensi untuk melakukan ikhtiyar mengkonstruksi atau membangun kembali sebuah lembaga pendidikan tinggi sebagai alternative pengganti AP NW yang ditutup dengan alasan persyaratan formal yang belum memadai. Akhirnya pada tahun 1974, atas kesepahaman antar dua lembaga sebagaimana dijelaskan di atas, Ma'had Darul Qur"an Wal-Hadits Al-Majidiyah Assyafiiyah Nahdlatul Wathan lil banat didirikan. Langkah ini sangatlah strategis secara organisatoris karena akan memungkinkan terselenggaranya kaderisasi disektor muslimat atau nahdliyat yang secara khusus diinternal organisasi tidak mudah diwujudkan. Kaderisasi melalui MDQH (Ma'had Darul Qur"an Wal-Hadits Al-Majidiyah Assyafiiyah Nahdlatul Wathan ) lil banat ini diharapkan agar dapat mengisi kepengurusan organisasi badan otonom Muslimat Nahdlatul Wathan secara berjenjang dari jenjang pusat, wilayah, daerah, cabang, anak cabang, dan ranting, bahkan kepengurusan di tingkat perwakilan yang ada. Dengan terwujudnya ekspektasi gerakan kaderisasi melalui jalur ini, maka "corong" atau juru bicara Organisasi Nahdlatul Wathan dalam kaitan pembangunan bidang pemberdayaan perempuan secara massif dapat terlaksana sesuai program kerja yang ditetapkan dalam setiap Muktamar, Konferensi, atau Musyawarah Organisasi Nahdlatul Wathan. Selanjutnya, pembangunan nasional terkait pemberdayaan perempuan yang dilaksanakan oleh pemerintah mendapatkan daya dukung positif dari Nahdlatul Wathan. Bagi Pemerintah tentu ini menjadi catatan khusus bagi Nahdlatul Wathan yang pada saatnya nanti akan mendapat apresiasi, utamanya dalam sharing program untuk melakukan akselerasi pencapaian tujuan pembangunan Nasional.

Walau Ma'had Darul Qur"an Wal-Hadits Al-Majidiyah Assyafiiyah Nahdlatul Wathan lil banat telah dibangun dan menunjukkan eksistensinya, untuk memanifestasikan kesepahaman gerakan, Yayasan Al-Mujahiddin dan Birrulwalidain Nahdlatul Wathan Pancor pada tahun 1974 melakukan 
penyesuaian secara administrative dengan mengacu pada peraturan perundang-undangan yang berlaku untuk mengajukan kembali pendirian beberapa perguruan tinggi. Karena upaya yang sungguh-sungguh, Pada tahun 1977 Nahdlatul Wathan yang bermitra dengan Yayasan Al-Mujahiddin dan Birrulwalidain Nahdlatul Wathan Pancor berhasil mendirikan Universitas Hamzanwadi. Namun karena aturan yang sangat sulit, Universitas HAMZANWADI pada tahun 1978 berubah status menjadi beberapa sekolah tinggi, antara lain, yaitu: STIT ( Sekolah Tinggi Ilmu Tarbiyah), STIS (Sekolah Tinggi Ilmu Syari'ah), STID (Sekolah Tinggi Ilmu Dakwah), dan STIP (Sekolah Tinggi Ilmu Pendidikan). Kebehasilan pendirian perguruan tinggi ini ternyata memiliki makna strategis tersendiri karena pada waktu pendiriannya, Negara memberlakukan secara Nasional kurikulum yang salah satu mata kuliahnya menyentuh kehidupan masyarakat. Misalnya dalam mata kuliah praktek kerja lapangan yang lebih dikenal dengan PPL (Praktek Pengalaman Lapangan) dan KKN ( Kuliah Kerja Nyata). Model penerapan kedua mata kuliah ini ada yang langsung menempatkan mahasiswa ke masyarakat umum dan ada juga pula yang ke lembaga-lembaga terkait, seperti sekolah atau madrasah untuk STIT ( Sekolah Tinggi Ilmu Tarbiyah) dan STIP (Sekolah Tinggi Ilmu Pendidikan), lembaga peradilan untuk STIS (Sekolah Tinggi Ilmu Syari'ah), dan masjid, majelis ta'lim, untuk mahasiswa STID (Sekolah Tinggi Ilmu Dakwah).

Model penerapan kurikulum nasional ini tentu membantu proses sosialisasi kelembagaan perguruan tinggi bersangkutan sekaligus Yayasan Al-Mujahiddin dan Birrulwalidain Nahdlatul Wathan Pancor, yang dulunya adalah NWDI-NBDI atau madrasah induk yang menjadi embrio organisasi Nahdlatul Wathan. Percaya atau tidak, sosialisasi ini telah banyak mendorong terkonstruksinya system social baru yang berafiliasi kepada Nahdlatul Wathan. Tidak sedikit pula yang akhirnya mampu menghadirkan pembentukan kepengurusan organisasi, seperti, jenjang ranting, anak cabang, cabang, bahkan perwakilan untuk daerah atau wilayah di luar Nusa Tenggara Barat yang dijadikan 
sasaran oleh Ma'had Darul Qur"an Wal-Hadits Al-Majidiyah Assyafiiyah Nahdlatul Wathan Pancor dalam kegiatan safari Ramadhan.

Selain penyelenggaraan mata kuliah dalm kurikulum Nasional sebagaimana penjelasan di atas, perguruan tinggi pada saat itu juga melaksanakan suatu aktivitas yang dikenal dengan kegiatan Tri Dharma Perguruan Tinggi. Kegiatan tersebut terdiri atas: Kagiatan Pendidikan dan Pengajaran, Kegiatan Penelitian, Kegiatan PPM ( Pengabdian Pada Masyarakat)

Kegiatan penelitian dan PPM (Pengabdian Pada Masyarakat) ini juga merupakan suatu kegiatan yang langsung atau pun tidak mem-fokuskan kegiatan di masyarakat umum dan ada juga pula yang ke lembaga-lembaga terkait. Kegiatan penelitian ini meliputi pengkajian masalah-masalah sosial-kemasyarakatan, dan fenomena alam. Pengajian ini kemudian dilakukan dengan mendialogkan fakta dan fenomena yang ditemukan dengan pelbgai teori ilmu pengetahuan, maupun teknologi. Hasil pengkajian tersebut kemudian lahir dalam bentuk solusi masalah sosial kemasyarakatan atau pun peristiwa alam, baik biologis maupun fisika. Solusi-solusi kemudian dipublikasi secara prosedural sehingga dapat dimanfaatkan oleh pihak-pihak terkait untuk melakukan pengentasan masalah, sekaligus inovasi dalam pembangunan yang bermanfaat bagi masyarakat, bangsa, dan Negara. Demikian pula dengan kegiatan PPM ( Pengabdian Pada Masyarakat). Kegiatan ini memusatkan perhatian pada implementasi ilmu pengetahuan dan teknologi dalam pengentasan masalah yang terjadi di tengah-tengah masyarakat. Tidak sedikit pula kegiatan PPM ( Pengabdian Pada Masyarakat) ini melaksanakan inovasi dalam beberapa aspek pembangunan di desa-desa binaan dengan menggerakkan atau memobilisasi tenaga relawan atau volunteer yang berasal dari internal kampus. Program kegiatan PPM (Pengabdian Pada Masyarakat) dengan pola desa binaan ini diformat dalam kemah bhakti sosial, gerakan penghijauan, safari ramadhan atau safari dakwah, penyuluhan dengan materi yang relevan dengan kebutuhan masyarakat, Kuliah 
Kerja Nyata, dan lain-lain. Dalam hal tertentu, kegiatan penelitian dan PPM (Pengabdian Pada Masyarakat) dilaksanakan secara bersamaan karena alasan penanganan sebuah masalah social kemasyarakatan dan peristiwa alam membutuhkan pengkajian yang matang sehingga solusi atau tindakan sebagai solusi dapat diberikan atau implementasikan dengan memenuhi standar efisiensi dan efektivitas. Kegiatan-kegiatan ini, sesungguhnya merupakan sebuah kerja yang mendatangkan kemanfaatan luar bisaa bagi internal kampus dan Yayasan Al-Mujahiddin dan Birrulwalidain Nahdlatul Wathan Pancor, serta Organisasi Nahdlatul Wathan. Baik Yayasan Al-Mujahiddin dan Birrulwalidain Nahdlatul Wathan Pancor maupun Organisasi Nahdlatul Wathan mendapatkan media atau pola alternative dalam melaksanakan program kerja bidang, pendidikan, social, dan dakwah Islamiyahnya. Dengan kegiatan ini, sosialisasi lembaga pendidikan dalam rangka recruit murid dan atau mahasiswa dapat terlaksana, bahkan melebihi efisiensi dan efektivitas dengan pola-pola yang lain. Alasannya adalah, kegiatan ini langsung ke objek sasaran dan dapat dilaksanakan secara bersama-sama dengan penguru organisasi pada jenjang ranting maupun anak cabang yang tentu memiliki akses dan kepercayaan yang tidak diragukan dari objek sasaran sosialisasi. Demikian pula halnya dengan kegiatan bidang social dan dakwah Islamiyah. Selain efektiv, juga memiliki effect positive berupa terselengaranya konsolidasi organisasi secara berjenjang. Konsolidasi yang kondusif ini tentu menjadikan organisasi menjadi kuat dan membidani integritas pengurus dan nahdliyin yang andal. Pemerintah sendiri tidak urung mendapat coat tail effect dari kegiatan penelitian dan PPM (Pengabdian Pada masyarakat) ini. Upaya pemerintah untuk mendorong kerja-kerja yang berpola swadaya dapat terbangun dibeberapa tempat yang dijadikan desa binaan oleh beberapa perguruan tinggi yang berada di bawah naungan Yayasan Al-Mujahiddin dan Birrulwalidain Nahdlatul Wathan Pancor.

Ternyata hambatan, tantangan, gangguan, dan ancaman memang tak kan berakhir hingga akhir pengkhidmatan di dunia. 
Demikian pula adanya dengan penghidmatan Nahdlatul Wathan. Setelah kelembagaan pendidikan tinggi mulai terstandar menurut aturan yang ada, system politik baru melakukan perubahan terkait dengan legitimasi kelembagaan. Pada waktu itu, tepatnya pada tahun 1982, pensyaratan pendirian sebuah perguruan tinggi wajib dilaksanakan oleh sebuah yayasan jika penyelenggaran pendidikan tinggi itu adalah unsur masyarakat. Pengurus Yayasan Al-Mujahiddin dan Birrulwalidain Nahdlatul Wathan Pancor dengan support organisasi Nahdlatul Wathan mulai berikhtiyar memenuhi pensyaratan tersebut. Yayasan Al-Mujahiddin dan Birrulwalidain Nahdlatul Wathan Pancor yang secara undangundang belum dipandang cukup memenuhi persyaratan mulai dibenahi dan diusulkan menjadi sebuah yayasan yang memenuhi ketentuan yang berlaku. Pemerintah tentu tidak menutup mata dengan kiprah Nahdlatul Wathan, khususnya Yayasan AlMujahiddin dan Birrulwalidain Nahdlatul Wathan Pancor yang fokus pada pembangunan sumberdaya manusia melalui jalur pendidikan. Demikian pula terhadap sikap positif Nahdlatul Wathan selama ini yang senantiasa bermitra dengan pemerintah, ternyata menjadi pertimbangan percepatan pemerosesan izin berdirinya yayasan baru yang diusulkan sebagaimana uraian di atas. Akhirnya pada tahun 1982 itu juga lahirrlah izin yayasan yang selanjutnya bernama Yayasan Pendidikan Hamzanwadi Pancor Pondok Pesantren Darunnahdlatain Nahdlatul Wathan (YPH PPD NW) Pancor. Dengan resminya yayasan tersebut maka perguruan tinggi yang telah didirikan sebelumnya menjadi berkedudukan hukum tetap serta dapat beroperasi melaksanakan Tri Dharma Perguruan Tingginya.

Mencermati proses izin pendirian Yayasan Pendidikan Hamzanwadi Pancor Pondok Pesantren Darunnahdlatain Nahdlatul Wathan (YPH PPD NW) Pancor tersebut, maka kita akan semakin yakin bahwa " politik pendidikan" di Nahdlatul Wathan sudah berjalan dengan begitu rapi. Selain kecepatan proses izin itu, alas pengajuan izin, utamanya kondisi lapangan yang terkait dengan keterlaksanaan pendidikan yang sudah ada secara wajar 
adalah bukti bahwa strategi antisipativ atas kemungkinan persoalan sebagaimana fakta pensyaratan pendirian yayasan penyelenggara pendidikan, benar-benar menjadi variable yang membuktikan konten politik pendidikan Nahdlatul Wathan cukup eksis. Coba bayangkan, jika kondisi lapangan sebagai bukti fisik pemenuhan pensyaratan tidak ada, maka dipastikan percepatan proses tidak akan terwujud, bahkan sangat mungkin izin tersebut tidak akan keluar.

Keberhasilan pendirian yayasan untuk kepentingan pemenuhan persyaratan tetap terselenggaranya beberapa perguruan tinggi yang ada, khususnya Sekolah Tinggi Keguruan dan Ilmu Pendidikan Hamzanwadi Selong, tampaknya menjadi langkah yang baik untuk melakukan usaha-usaha pengembangan kelembagaan perguruan tinggi, sekaligus memperluas dan mengoptimalkan daya organisasi dalam mempersiapkan kadernya untuk kepentingan penyelenggaraan program kerja organisasi Nahdlatul Wathan yang senantiasa sejalan dengan Program Pembangunan Nasional atau PROPENAS yang tertuang dalam Garis-Garis Besar Haluan Negara (GBHN). Sekitar tahun 1982, di mana Yayasan Pendidikan Hamzanwadi Pondok Pesantren Nahdlatul Wathan Pancor mendapat legitimasi formal, Negara tengah focus pada pencanangan penguatan pemeliharaan lingkungan hidup, utamanya di wilayah kehutanan dan pantai. Fokus kerja pemerintah ini kemudian mendapat support dari beberapa perguruan tinggi yang ada di lingkungan Yayasan Pendidikan Hamzanwadi Pondok Pesantren Nahdlatul Wathan Pancor. Bentuk dukungan yang diberikan oleh beberapa perguruan tinggi tersebut adalah program Pengabdian Pada Masyarakat (PPM) dengan aspek kegiatan Kuliah Kerja Nyata (KKN), dan Kemah Bhakti Sosial. Dalam konteks penjelasan di atas ini, bentuk dan jenis dukungan Yayasan Pendidikan Hamzanwadi Pondok Pesantren Nahdlatul Wathan Pancor sesungguhnya bukan yang utama. Yang menurut peneliti strategis adalah bagaimana kecermatan beberapa perguruan tinnggi yang ada tersebut mempersiapkan kader-kader melalui kegiatan akademik dan non 
akademiknya. Selain itu, aspek yang menarik adalah kemampuan perguruan tinggi memberdayakan masyarakat di tempat Pengabdian Pada Masyarakat (PPM) dan Kuliah Kerja Nyata (KKN) dilaksanakan. Dua hal yang strategis dan menarik ini membuktikan bahwa system pemberdayaan masyarakat telah sangat efektiv dilakukan oleh Organisasi Nahdlatul Wathan melalui perguruan tinggi yang diselenggarakan oleh Yayasan Pendidikan Hamzanwadi Pondok Pesantren Nahdlatul Wathan Pancor.

Nahdlatul Wathan yang terkenal koopratif dan istiqomah melaksanakan kemitraan dengan pihak pemerintah penguasa, tidak berarti selalu mengamini seluruh kebijakan dan pilihanpilihan mainstream atau cenderung oportunis (melaksanakan politik pucuk aru). Nahdlatul Wathan menetapkan pilihan sesungguhnya berdasarkan pertimbangan kemanfaatan. Jika mainstream menentukan sebuah pilihan yang mendatangkan manfaat bagi kepentingan yang luas, maka Nahdlatul Wathan akan berada dalam satu barisan dengan mainstream tersebut. Sementara, jika pilihan mainstream mendatangkan mudarat, maka Nahdlatul Wathan berada di pihak yang berseberangan. Sikap ini menunjukkan keteguhan Organisasi Nahdlaul Wathan dalam memegang teguh semboyan " Nahdlatul Wathan Fil-Khair Nahdlayul Wathan Fastabiqul Khairat. Pada tahun 1982 peristiwa "NW berani berbeda" dengan kekuatan mainstream menjadi sebuah bukti yang kuat bahwa Organisasi Nahdlatul Wathan bukan ORMAS yang oportunis. Ketika itu, Nahdlatul Wathan berdasarkan sikap tegas pendirinya, Almagfurlahu Maulanasysyaikh TGKH Muhammad Zainuddin Abdul Majid Pancor atau Bapak Hamzanwadi, mengambil hak diam dalam PEMILU 1982. Artinya Organisasi Nahdlatul Wathan tidak mendukung salah satu partai kontestan pada PEMILU 1982 tersebut. Sikap ini tentu karena pertimbangan manfaat-mudarat yang tidak hanya dalam kaitan dengan internal Nahdlatul Wathan, tetapi juga terkait dengan kepentingan Bangsa dan Negara. Yang perlu dicermati dalam peristiwa tahun 1982 ini adalah 
terlaksananya suatu system pertahanan diri Organisasi Nahdlatul Wathan. Seluruh unsur pengurus organisasi secara berjenjang dari Pengurus Besar Nahdlatul Wathan samapai Pengurus Anak Cabang, bahkan Ranting Nahdlatul Wathan di desa-desa dalam kondisi satu bahasa, gerak dan langkah mengamankan sikap diam Organisasi Nahdlatul Wathan. Ajaran "Kompak Utuh Bersatu" yang ditanamkan Bapak Hamzanwadi ketika itu betul-betul saatnya dinikmati oleh keluarga besar Nahdlatul Wathan. Tidak dapat dipungkiri, bahwa peristiwa pelaksanaan hak diam yang begitu hebat dan dahsyat itu, serta-merta mengubah peta kekuatan politik, khususnya di Nusa Tenggara Barat. Salah satu partai peserta kontestasi PEMLU 1982 yang sebelumnya adalah mainstream, saat itu menjadi kekuatan yang tidak mencolok sebagaimana kondisi PEMILU sebelumnya. Sementara iru, partaipartai lainnya dapat merebut kantong-kantong suara lebih banyak dan hasilnya tentu dapat melebihi target-target yang mereka tetapkan secara internal. Fakta ini menjadi sebuah pembelajaran berharga bagi keluarga Besar Nahdlatul Wathan. Mereka rata-rata menyadari bahwa sesungguhnya Nahdlatul Wathan dengan ajaran "Kompak Utuh Bersatu" ternyata bisa menjadi pihak yang mengatur, atau justeru dapat hadir sebagai mainstream, khususnya di Nusa Tenggara Barat. Keluarga Besar Nahdlatul Wathan kemudian menjadikan peristiwa pengambilan hak diam dalam agenda politik praktis tersebut menjadi test case yang suatu saat nanti, bila memungkinkan akan diberdayakan, khususnya dalam usaha mewujudkan " Nahdlatul Wathan Fil-Khair Nahdlayul Wathan Fastabiqul Khairat. Pembelajaran yang cukup luar bisaa dan efektiv itu, secara internal menghadirkan rasa percaya yang mendalam kepada elite dalam tubuh organisasi, khususnya kepada Bapak Hamzanwadi selaku Pendiri Nahdlatul Wathan. Artinya, otoritas elite Nahdlatul Wathan semakin menguat sehingga putusan-putusan organisasi akan menjadi pertimbangan utama (preliminary) bagi nahdliyin dalam mengambil sikap dan tindakan, khususnya terkait dengan hak politik mereka. Otoritas yang terjadi sebagai fakta perilaku 
berorganisasi di Nahdlatul Wathan pasca berlangsungnya hak diam secara massif itu tidak persis sama seperti yang dinyatakan oleh para ahli. Misalnya saja Dehendrof, seorang ahli dalam teori pertukaran dan konflik, menyatakan bahwa otoritas itu tidak konstan karena tidak berada dalam diri seseorang, melainkan statusnya dalam sebuah kelompok (George Ritzer: 155). Yang terjadi di Nahdlatul Wathan adalah menguatnya otoritas tersebut secar total, baik dalam tinjauan status seseorang sebagai sumber otoritas maupun individu tokoh secara parsial. Bukanlah hal bisaa. Fakta ini adalah sebuah peristiwa incredible yang melampau batasan-batasan produk research yang sudah popular, seperti yang dikemukakan di atas. Ketika peneliti melakukan konfirmasi atas formula fakta ini, seorang senioritas dalam tubuh Organisasi Nahdlatul Wathan menegaskan bahwa peristiwa ini memang unik. Latar kuat yang menkonstruksinya adalah akumulasi pengalaman nahdliyin dalam menerima ajaran dan fatwa dari Bapak Hamzanwadi dan atau keputusan organisasi yang juga mengacu pada pertimbangan yang diberikan oleh Bapak Hamzanwadi selaku pendiri yang disampaikan oleh para elite, senantiasa terbukti benar dan bermanfaat bagi seluruh nahdliyin, bahkan ummat secara kaffah di wilayah di mana gerakan Nahdlatul Wathan ada. Lebih lanjut dijelaskan bahwa, kebenaran-kebenaran yang diyakini oleh nahdliyin kemudian menjadi melegenda dimasing-masing lingkungan keluarga nahdliyin, sehingga menjadi sesuatu yang menguat, bahkan hampir seperti sebuah pegangan yang wajib ditaati. Salah seorang aktivis Nahdlatul Wathan yang juga menjadi ketua Lajnah Pengkaderan Nahdlatul Wathan ketika diwawancarai beliau memberikan keterangan bahwa penanaman nilai-nilai, termasuk nilai asasi " sami'na wa'ato'na ", khususnya kepada pimpinan diberikan secara terencana melalui majelis ta'lim yang diselenggarakan oleh Departemen Dakwah Islamiyah di tingkat Cabang, Anak Cabang, dan Ranting Nahdlatul Wathan. Selebihnya, penanaman nlai-nilai ini ditanamkan secara terintegrasi dengan kegiatan Hizib mingguan di setiap Ranting. Dalam momentum tertentu, penanaman nilai-nilai tersebut 
diintegrasikan dalam suatu agenda regular, seperti Peringatan Hari Besar Islam, Nahdlatul Wathan dengan menyelenggarakan Pengajian Umum organisasi setingkat Pengurus Daerah dan atau Pengurus Wilayah Nahdlatul Wathan. Seentara itu, sekali setahun, Nahdlatul Wathan secara bersama-sama dengan Yayasan Pendidikan Hamzanwadi Pondok Pesantren Nahdlatul Wathan Pancor melaksanakan sunnatan hasanah yang ditradisikan oleh Bapak Hamzanwadi dan dikenal dengan nama Kegiatan HULTAH NWDI. Dalam kegiatan ini diadakan pelbagai kegiatan yang bertaraf nasional, seperti seminar, workshop, kegiatan social kemasyarakatan, Rapat Kerja Nasional Organisasi, dan diakhiri dengan kegiatan Pengajian Umum HULTAH NWDI yang bertema “ Peran Serta Nahdlatul Wathan Dalam Pembangunan Nasional".

Mencermati kegiatan-kegiatan tersebut di atas, terutama terkait dengan kristalisasi nilai-nilai yang menkonstruksi kepercayaan penuh nahdliyin kepada organisasi dan para elitenya pada pengkhidmatan diera Orde Baru, khususnya pada tahun 1982, tampaknya Nahdlatul Wathan telah menerapkan polarisasi yang sangat rapi. Organisasi Nahdlatul Wathan betul-betul memberdayakan potensi yang dia miliki. Salah satu yang potensi yang paling mencolok diberdayakan adalah tahapan penanaman nilai melalui jenjang organisasi dari Ranting, Anak Cabang, Cabang, Pengurus Daerah, Pengurus Wilayah, sampai tarap yang melibatkan Pengurus Besar Nahdlatul Wathan. Artinya pentahapan penyelenggaraan penanaman atau kristalisasi nilainilai yang diharapkan akan memformat karakter nahdliyin pada tahun 1982 tersebut telah mengikuti birograsi system kerja organisasi sebagaimna yang telah ditetapkan dalam Anggaran dasar dan Anggaran Rumah Tangga hasil Muktamar Nahdlatul Wathan. Paradigma atau polarisasi kerja organisasi seperti ini termasuk kelompok organisasi modern. Inilah hal-hal di antara yang membanggakan dari organisasi Nahdlatul Wathan.

Modernitas Nahdlatul Wathan yang ditandai dengan pemberdayaan elemen-elemen organisasinya tidak bias dipungkiri. Selain jalur organisasi induk, badan-badan otonom 
juga diusahakan efektiv dan digerakkan secara berjenjang. Misalnya saja kepengurusan pemuda di tingkat Ranting yang berpusat di level kekadusan atau lingkungan, dijadikan pioneer rekruitmen anggota baru. Artinya, pimpinan pusat tidak melakukan kooptasi kerja pada jenjang kepengurusan dii bawahnya, apalagi sampai tingkat ranting. Jadi keteraturan berorganisasi pada level Pemuda Nahdlatul sebagai organisasi sayap atau otonom juga sangatlah taat azas pada norma-norma birokrasi, sesuai Anggaran Dasar dan Anggaran Rumah Tangga yang ada. Mas'ud Wajdi seorang aktivis Pemuda Nahdlatul Wathan memberikan penjelasan bahwa ketika Pemuda Nahdlatul Wathan dalam periodeisasi kepemimpinan Bapak Ma'sum Ahmad, BA sekitar tahun 1980 sampai dengan 1990, benar-benar memberikan kebanggaan sendiri bagi nahdliyin, khususnya di kalangan para pemuda di Nusa Tenggara Barat. Menjadi Pemuda Nahdlatul Wathan saat itu menjadikan kita tersanjung karena memiliki persyaratan sebagai Organisasi Formal modern. Jangankan identitas-identitas, fasilitas kantor dan kendaraan operasional pun dapat diadakan, walaupun melalui bantuan langsung Dewan Mustasyar Pengurus Besar Nahdlatul Wathan.

Muslimat Nahdlatul Wathan yang juga merupakan organisasi sayap atau Badan Otonom di lingkungan Nahdlatul Wathan, terus mengoptimalkan gerakannya secara terencana. Pada saat itu, Muslimat Nahdlatul Wathan dipimpin oleh Ummi Hajjah Siti Rauhun Zainuddin Abdul Majid. Sebagai organisasi yang memiliki jenjang yang lengkap, yaitu mulai dari Pimpinan Pusat, Pimpinan Wilayah, Pimpinan Daerah, Pimpinan Cabang, Pimpinan Anak Cabang, dan Pengurus Ranting, Muslimat Nahdlatul Wathan sangat terbantu dalam pengembangan dirinya. Sebagaimana Pemuda Nahdlatul Wathan, muslimat juga melakukan pembagian kewenangan secara proporsional kepada jenjang-jenjang organisasi yang ada. Dengan adanya pembagian kewenangan ini maka seluruh jenjang menjadi memiliki self of belonging sekaligus possesiv sehingga seluruhnya berdinamika secara simultan. 
Jelang tahun 1986, Himpunan Mahasiswa Nahdlatul Wathan juga semakin bangkit. Walau hanya memiliki jenjang Pimpinan Pusat, Pimpinan Cabang, dan Komisariat, Dari jenjang yang ada, hanya Komisariat yang sangat efektiv dalam melakukan mobilisasi kegiatan. Dinamisasi organisasi yang sedemikian rupa akhirnya mewujudkan capaian Himpunan Mahasiswa Nahdlatul Wathan berupa keberhasilan berdiaspora di kampus-kampus negeri atau swasta, khususnya yang ada di Pulau Lombok, dan Jawa. Keberadaan Himpunan Mahasiswa Nahdlatul Wathan yang hanya berbasis di kampus, tidak menjadikan ia kekurangan kreasi dalam hal pengembangan dirinya. Artinya, itu semua tidak menghalangi Himpunan Mahasiswa Nahdlatul Wathan untuk berinvestasi membumikan kepercayaan kepada masyarakat tentang pentingnya kekompakan dan kesertaan dalam pembangunan bangsa.

Selain perkembangan yang menggembirakan, sebagaimana uraian di atas, dalam mekanisme kepemimpinan nasional lima tahunan yang berlangsung sejak tahun 1982 hingga 1986, banyak sekali tantangan yang dihadapai, khususnya oleh Nahdlatul Wathan. Tantangan tersebut terkait dengan hadirnya multi kepentingan para kader yang telah masuk dalam kancah politik praktis dari pelbagai partai sebagai konsekuensi logis sikap diam organisasi pada Pemilu 1982 yang dimaknai sebagai adanya kebebasan berekspresi dalam hal penyelenggaraan hak politik oleh segenap nahdliyin. Kepentingan-kepentingan tersebut kemudian berbenturan dan ada pula yang sengaja dibenturkan melalui provokasi, khususnya dikalangan masyarakat atau warga Nahdlatul Wathan. Akibat kepentingan yang saling berebut pengaruh ini, warga hampir kehilangan pedoman dalam hal memilih jalur yang diikuti, khususnya pada pelaksanaan hak dan kewajiban mereka sebagai warga Nahdlatul Wathan, masyarakat, dan Negara. Situasi ini tidak dapat ditutup-tutupi karena masingmasing penganut kepentingan berusaha menyampaikan perspektif mereka kepada Bapak Hamzanwadi dan pengurus organisasi. Nuansa perbedaan yang cukup tajam ini kemudian diserap sebagai 
informasi penting yang harus disikapi secara organisatoris oleh elite organisasi Nahdlatul Wathan, temasuk Bapak Hamzanwadi yang saat itu bertindak selaku Ro'is Amm Dewan Mustasyar Pengurus Besar nahdlatul Wathan. Khususnya Bapak Hamzanwadi, selaku pendiri Nahdlatul Wathan tentu tidak menginginkan konflik-konflik seperti ini akan menjadi penyebab munculnya perpecahan di kalangan nahdliyin atau jamaahnya. Beliau menyadari bahwa jika konflik horizontal ini mekar dan tidak diabaikan maka akan menjadi ancaman bagi kelangsungan keberadaan organisasi. Maka oleh karena itu, Bapak Hamzanwadi dengan sangat arif dan hati-hati menentukan strategi dalam pemecahan masalah ini, sehingga menghasilkan sebuah penyelesaian yang akan mengutuhkan kekompakan nahdliyin. Sebagaimana para ahli mensinyalir bahwa seluruh pengaduan, apalagi yang berbeda-beda adalah issue di mana kita tidak dapat menjelaskannya secara parsial dari kontinum subjektivias dan objektivitas. Atas dasar itu kemudian Bapak Hamzanwadi secara seksama melakukan pengkajian untuk menjawab ketakpastian informasi akibat beberapa kepentingan dari sumber informasi yang tidak lain adalah jamaah-jamaah beliau. Dalam situasi ini, Bapak Hamzanwadi sering mengilustrasikan posisi dirinya sebagai “ Korban Cinta dan Kecintaan." Makna pernyataan Pendiri Nahdlatul Wathan ini adalah bahwa sesungguhnya seluruh jamaah pengadu dan apa yang diadukan adalah dalam kerangka merebut kecintaannya dan tentu digiring oleh keinginan mereka menjadi yang terdekat dan paling mencintai Namun demikian, Bapak Hamzanwadi tidaklah larut dalam perasaannya. Beliau juga orang atau sosok pimpinan yang cerdas dan memiliki prinsip yang kuat. "kulil haqqo walaukana murron". Karena itu pula dengan alasan ketakpastian sebagaimana diutarakan diatas, penelusuran informasi mulai dilaksanakan dengan cara-cara yang rapi. Pragmatisme yang dilakukan Bapak Hamzanwadi ini selaras yang dinyatakan oleh Cahrles Sander Pierce, dalam M. Arfan, Abdul Wahid Hasan, dan kawan-kawan, bahwa pengkajian mulai berlangsung ketika seseorang mulai ragu atas apa yang diyakini 
sebelumnya (Arfan, 2013: 40). Setelah beberapa informasi terkumpul dan dapat menjadi representasi dari kondisi yang sebenarnya terjadi, beliau merumuskan kesimpulan untuk kembali pada system penyelenggaraan hak dan kewajiban nahdliyin, khususnya dalam sikap politik untuk berada pada satu pilihan. Tentu pilihan-pilihan yang akan ditentukan organisasi adalah yang berdasarkan kesepakatan bersama. Untuk memantapkan putusan ini, maka dalam Muktamar VIII Nahdlatul Wathan tahun 1986 dilakukan pembahasan dan tampaknya muktamirin memiliki pandangan yang sama untuk tetap berada dalam satu pilihan secara organisatoris. Artinya, bila ada yang memiliki pilihan berbeda maka itu adalah pilihan kasus perkasus di luar tanggungjawab organisasi.

Tampaknya pada tahun politik 1986, fenomena sosial sisi makro dilingkungan Nahdlatul Wathan diberdayakan kembali. Sebagimana yang dinyatakan Ritzer, bahwa aspek makro dari fenomena sosial terdiri atas makro objektiv dan makro subjektiv. Makro objektiv terdiri atas: masyarakat, hukum, birokrasi, arsitektur, teknologi, dan bahasa. Sementara itu, sisi makro subjektiv terdiri atas: budaya, norma, dan nilai (George Ritzer, 2005: 476). Artinya sikap yang diambil oleh pendiri Nahdlatul Wathan sekaligus organisasi dalam hal penentuan arah kemitraan secara umum ditentukan oleh birokrasi organisasi dengan berdasarkan pada norma atau ketentuan yang berlaku. Keputusan ini tidak lagi berfihak pada fenomena social mikro yang memberikan peluang seluas-luasnya bagi individu sebagai warga atau aktor dalam organisasi. Hal ini ditegaskan jika menjawab Kelner yang menyatakan bahwa harus ada beda yang jelas antara makro dan mikro dalam suatu deskrepsi atau penjelasan tertentu (George Ritzer, 2005: 474-475).

Setelah kebijakan tersebut kemudian Nahdlatul Wathan mulai menguat, baik secara internal maupun eksternal. Secara internal, penguatan Nahdlatul Wathan tersebut ditunjukkan dengan aktivitas serta produktivitasnya yang lebih baik dan banyak dari periode sebelumnya. Misalnya saja dari sisi variasi kegiatan sudah 
cukup berkembang, utamanya terlihat pada aspek harakah social Nahdlatul Wathan. Ini tentu sangat positip bagi Nahdlatul Wathan. Selain meyakinkan kembali warganya, juga dapat mempetontonkan kembali eksistensi Nahdlatul wathan dalam pembangunan bidang social kemasyarakatan. Sedangkan dari sisi eksternal, Nahdlatul Wathan dapat memberikan kepastian dalam transaksi kemitraan dengan relasi-relasinya, termasuk dalam konteks penentuan kemitraan dalam penyaluran hak politik warga Nahdlatul Wathan. Dalam sebuah wawancara dengan salah seorang pengurus organisasi pada tahun 1986 itu, ditegaskan bahwa: Nahdlatul Wathan setelah kembali memutuskan untuk satu kendali dalam penyaluran hak politik warga, Nahdlatul Wathan mengalami kemudahan-kemudahan, baik dalam mengkoordinasikan keputusan dan penetapan sikap, maupun dalam hal memberikan kepastian yang meyakinkan kepada relasi kemitraan. Selain dari itu, Nahdlatul Wathan dapat menghasilkan capaian-capaian yang optimal, terutama terkait dengan konsekuensi dari berjalannya sebuah kemitraan sebagimana diuraikan di atas.

Ada beberapa faktor yang tampaknya sangat berperan dalam kelancaran koordinasi dan pemberdayaan nahdliyin setelah fungsionalisasi struktur dilaksanakan pada Muktamar VIII, yaitu: intensitas kegiatan sosial yang menyentuh keluarga, adanya koordinasi yang seimbang antar dua mainstream (Nahdlatul Wathan dan Golkar sebagai partai politik terbesar di Indonesia), dan terkondisinya komitmen kader yang dikaryakan melalui pelbagai jalur, khususnya di karir birokrasi pemerintah.

Kegiatan sosial seperti pembinaan Pasangan Usia Subur (PUS) melalui lembaga Balai Kesehatan Ibu dan Anak Nahdlatul Wathan yang bermitra dengan Pusat Kesehatan Pondok Pesantren Hamzanwadi Pancor, sangatlah efektiv. Pola pemberdayaan yang melibatkan kader-kader Ranting Nahdlatul Wathan dengan panduan kerja yang ditetapkan secara terpadu oleh organisasi sangat membangkitkan rasa tanggung-jawab kader dalam mengemban amanah yang tertuang dalam program kerja 
Nahdlatul Wathan. Rasa tanggungjawab yang sedemikian bagus itu, kemudian secara berjenjang sampai ke tingkat anggota keluarga nahdliyin seperti "saling sahut menyahut" (fenomena gayung bersambut). Sementara itu, dalam perspektif button-up, kondisi yang saling mensupport ini pun berlangsung persis sama. Jenjang di atas Ranting, seperti Anak Cabang, Cabang, Daerah, dan seterusnya menjadi berdinamika, utamanya dalam proses kanalisasi laporan pertanggungjawaban pelaksanaan program dan publikasi garis-garis kebijakan oganisasi sebagai pedoman serta fasilitasi penyelenggaran program kerja secara berjenjang. Dalam aktivitas ini tampak sekali aktivitas mikro-makro yang saling member ruang dalam sistem organisasi Nahdlatul Wathan. Dalam sebuah kesempatan, Hj. Nurjannah Ma'sum memberikan keterangan bahwa: setelah Muktamar VIII Nahdlatul Wathan, seluruh kegiatan cukup terkoordinasi. Para pelaksana di tingkat Anak cabang dan Ranting sebagai pioneer Organisasi Nahdlatul Wathan menunjukkan etos kerja yang membanggakan. Sementara itu, para penentu kebijakan organisasi pun sangat memahami apa yang perlu mereka laksanakan untuk melakukan mediasi dan fasilitasi agar penyelenggaraan kegiatan oleh jenjang organisasi di tingkat Ranting dan Anak Cabang nahdlatul Wathan dapat berjalan dengan baik dan tentu menghasilkan produk kerja yang bermanfaat dan optimal. Semangat kerja dan hasil kerja semakin terpacu, ketika Nahdlatul Wathan dengan BP3M NW (Badan Pendidikan, Pembinaan, dan Pengembangan Masyarakat Nahdlatul Wathan ) yang merupakan Badan Non Otonomnya berhasil memakmurkan kegiatan pemberdayaan organisasi dan nahdliyin. Beberapa kegiatan sebagaimana diuraikan di Bab sebelumnya, Tampaknya BP3M NW (Badan Pendidikan, Pembinaan, dan Pengembangan Masyarakat Nahdlatul Wathan) fokus pada fasilitasi yang mengkondisikan nahdliyin dapat memenuhi capaian-capaian yang mengantar mereka pada kehidupan yang lebih baik. Misalnya saja, kegiatan imunisasi dan program KB (Keluarga Berencana). Program yang diperuntukkan kepada nahdliyin ini adalah usaha dasar untuk memperbaiki 
kapasitas nahdliyin dan atau ummat pada umumnya dalam melaksanakan tugas dan kewajibannya sebagai warga masyarakat, bangsa, dan Negara. Buktinya adalah dengan penjaminan kesehatan anggota keluarga nahdliyin atau ummat serta perbaikan rasio kapasitas ekonomi dan jumlah anggota keluarga dalam satu kepala keluarga, maka tingkat lesejahteraan tentu dapat diperbaiki secara optimal. Dengan usaha seperti ini dan secara langsung dinikmati oleh nahdliyin atau ummat maka tidak bias dipungkiri kalau akan terjadi gerak perbandingan searah dengan kebanggaan nahdliyin atau ummat menjadi bagian dari Nahdlatul Wathan. Apalagi dalam penyelenggaraannya ini, BP3M NW (Badan Pendidikan, Pembinaan, dan Pengembangan Masyarakat Nahdlatul Wathan) berbasis pada pemberdayaan kader-kader organisasi dari tingkat Pusat, Wilayah, daerah, Cabang, Anak Cabang, dan Ranting Nahdlatul Wathan. Semakin bergensi lagi karena program ini merupakan kerjasama dengan tidak hanya instansi pemerintah pusat maupun daerah, tetapi juga bekerjasama dengan Badan Internasional Perserikatan BangsaBangsa, yaitu UNICEF. Sabri Waas, BA, seorang aktivis BP3M NW (Badan Pendidikan, Pembinaan, dan Pengembangan masyarakat Nahdlatul Wathan ) menjelaskan bahwa dinamika kegiatan yang menjadi focus kerja BP3M NW (Badan Pendidikan, Pembinaan, dan Pengembangan Masyarakat Nahdlatul Wathan) sangatlah cepat dan bervolume banyak, lagi intensif. Dinamika dan volume yang sedemikian rupa ini dikarenakan, BP3M NW (Badan Pendidikan, Pembinaan, dan Pengembangan Masyarakat Nahdlatul Wathan) ini memberdayakan seluruh komponen organisasi dalam menyelenggarakan kegiatan yang sangat dibutuhkan oleh nahdliyin dan juga ummat. Demikian pula yang dinyatakan oleh Pengurus Cabang Nahdlatul Wathan. Salah satunya adalah Pengurus Cabang Selong yang menyatakan bahwa, BP3M NW (Badan Pendidikan, Pembinaan, dan Pengembangan Masyarakat Nahdlatul Wathan) ini sangat memberikan manfaat tersendiri bagi ummat dan sangat produktif sampa dengan sekitar tahun 1994. 
Sejak 1995 sampai dengan 1997, aktivitas organisasi Nahdlatul Wathan mengalami masa-masa sulit karena beberapa factor, diantaranya adalah pendiri Nahdlatul Wathan dalam keadaan sakit, dan organisasi lebih focus pada dalam aktivitas internal untuk menjaga serta merawat keutuhan dan kekompakan nahdliyin. Pada tanggal 20 Oktober 1997 Pendiri NW, Almagfurulahu Maulansysyaikh TGKH. Muhammad Zainuddin Abdul majid Wafat. Ahun 1997 hingga 1998 Nahdlatul Wathan dalam konflik internal dan bersamaan dengan hal itu terjadi sebuah agenda nasional yang menghadirkan suatu babak baru periodeisasi kepemimpinan nasional yang dikenal dengan Era Reformasi.

\section{KESIMPULAN}

Nahdlatul Wathan sepanjang Era Orde Baru senantiasa berusaha berdinamika untuk mewujudkan Nahdlatul Wathan Fil-khair dan Nahdlatul Wathan Fastabiqul Khairat. Dalam usahanya itu Nahdlatul Wathan memberi ruang kepada sector mikro-makronya dengan motivasi sebagaimana dalam Wasiat Pendiri Nahdlatul Wathan yang menegaskan, "Sesungguhnya yang paling mulia di sisiku adalah yang paling bermanfaat untuk Nahdlatul Wathan Sementara sejahat-jahatmu di sisiku adalah yang berbuat buruk kepada Nahdlatul Wathan." Efek dari ruang yang dibuka dengan mesin pendorong dari semangat wasiat tersebut, mikro-makro organisasi terlibat secara massif, sehingga Nahdlatul Wathan tidak hanya berdenyut tumbuh dan berkembang untuk dirinya sendiri, melainkan Nahdlatul Wathan hadir pula untuk negeri, bahkan untuk rahmatan lil alamin. Wallohu'alamu.

\section{DAFTAR PUSTAKA}

Creswell, J. W. 2015. Penelitian Kualitatif, Desain Reasearch: Yoguakarta, Pustaka Pelajar 
Emzir. 2012. Metodologi Penelitian Kualitatif Analisis Data. Jakarta: Rajawali Pers.

Jamiluddin. 2002. Biografi Tokoh Hamzanwadi (TGKH.Muhammad Zainuddin Abdul Majid. Jakarta: Pusat Perbukuan RI.

Kanto, S. 1998. Kumpulan Materi Pelatihan Metodologi Penelitian, Sampling, validitas, dan reliabilitas Dalam Penelitian Kualitatif. Surabaya: Bamus PTSI.

Latif, Y. 2015. Genealogi Inteligensia, Pengetahuan dan Kekuasaan Inteligensia Muslim Indonesia Abad XX. Jakarta: Prenada Media.

Mu'ammar, M. A. \& Hasan, A. W. 2013. Studi Islam Perspektif Insider/ outsider. Yogyakarta:Ircisod,

Ritzer, G. \& Goddman, D. 2016. Teori Sosiologi Modern Edisi Keenam Ritzer, G. 2005. Teori Sosiologi Modern. Jakarta, Prenada Media.

Zainuddin, M. 1976. Ringkasan Sejarah Nahdlatul Wathan. Pancor: Sejretariat NW 